\title{
Existence and Removal of Rotaviruses Group A and Cryptosporidium Species in a Wastewater Treatment Plant
}

\author{
Neveen Rizk ${ }^{1}$, Ahmad Al-Herrawy ${ }^{2}$, Mahmoud Gad ${ }^{2 *}$, \\ Mohamed Shaheen ${ }^{1}$, Elmahdy Elmahdy ${ }^{1}$ \\ ${ }^{1}$ Environmental Virology Lab, Water Pollution Research Department, National Research Centre, Giza, Egypt \\ ${ }^{2}$ Environmental Parasitology Lab, Water Pollution Research Department, National Research Centre, Giza, Egypt
}

Received: 24 July 2018

Accepted: 24 September 2018

\begin{abstract}
Rotavirus group A (RV-A) and Cryptosporidium spp. are recognized as important pathogens causing gastroenteritis, even with very low doses in all age groups and representing a public health risk. Seventy-two wastewater samples were collected and concentrated for detecting Cryptosporidium spp. and RV-A. PCR was performed for identification of genus Cryptosporidium using generic primers and species specific primers for Cryptosporidium parvum / Cryptosporidium hominis. Multiplex seminested RT-PCR was performed to identify the genotypes P and G of RV-A. Our findings showed that the rotavirus genome was detected in $29(40.3 \%)$ out of 72 analyzed wastewater samples. Rotavirus rates in raw wastewater samples were higher (47.2\%) than those detected in treated wastewater (33.3\%). Cryptosporidium was found in $33.3 \%$ of 72 tested wastewater samples. All Cryptosporidium-positivesamples were related to Cryptosporidium parvum. The prevalence of Cryptosporidium parvum in influents and effluents reached $41.7 \%$ and $25 \%$, respectively. The removal rates of rotavirus and Cryptosporidium parvum in the examined WWTP were $29.4 \%$ and $40 \%$, respectively. The largest percentage of positive rotavirus in raw wastewater samples was detected in winter (77.8\%), followed by $66.7 \%$ in autumn. Three P types and two G types of RV-A strains were identified in wastewater samples. The most prevalent types of RV-A strains in raw and treated sewage samples were G1 and P[8] genotypes. In conclusion, wastewater treatment processes, including a trickling filter, were not sufficient to eliminate several RV-A strains and Cryptosporidium parvum, leading to the potential release of these pathogens from domestic sewage into water sources.
\end{abstract}

Keywords: rotavirus genotypes, Cryptosporidium spp., removal, wastewater, multiplex RT-PCR

*e-mail: mahmoudafw@gmail.com 


\section{Introduction}

A protozoan Cryptosporidium is a parasite that infects various animal species and humans [1]. Its zoonotic potential as well as its ubiquitous presence in numerous animal species and the environment is confirmed. Globally, Cryptosporidium is a major contributor of diarrheal diseases in young farm animals and causes about $20 \%$ of diarrheal episodes in children of developing countries [2,3]. The largest documented waterborne parasitic disease outbreak in history is attributed to this organism and to date it remains refractory to all conventional treatments. Cryptosporidium is also extremely resistant to disinfection [2]. Comparatively, PCR techniques are more sensitive and specific than conventional diagnostic microscopy for the detection of Cryptosporidium in clinical and environmental samples [4]. Many species of Cryptosporidium are of little public health significance, however the vast majority of human cryptosporidiosis is caused by Cryptosporidium parvum and Cryptosporidium hominis [2]. Worldwide, severe gastroenteritis caused by human rotaviruses group A are responsible for about 600,000 deaths annually in infants and children [5]. In developed countries, rotaviruses are considered a common cause of morbidity with a considerable economic burden [6]. Children 5 years old are most susceptible to rotavirus infection, and reinfection may occur during life [6]. The genome of rotaviruses is composed of double helix molecules of RNA with 11 segments, encoding six viral proteins (VPs) that form the virus particle and six nonstructural proteins (NSPs) [6]. Rotaviruses group A are classified according to genes encoding the outer capsid proteins (glycoprotein) which define $\mathrm{G}$ type and protease-cleaved proteins which define P genotypes. About $37 \mathrm{P}$ and $27 \mathrm{G}$ rotavirus genotypes have been detected in humans and animals [7]. Only a limited number of GxP[y] genotypes confederations are popular in humans, such as G1P[8], G2P[4], G3P[8], G4P[8], and G9P[8][7], and unusual combinations such as G8P[4], G12P[8], G3P[9], G10P[8], G10P[14] and G1P[4] have also been reported lately [8-10].

The transmission of Cryptosporidium and rotavirus occurs by the consumption of contaminated water and food or from person to person through fecal-oral route. These pathogens are stable in the environment for a long period of time. After replication in the gastrointestinal tract, viruses are shed at very high concentrations of up to $10^{10}$ viruses/g in feces $[3,6]$. The main purpose of advanced wastewater treatment is to eliminate/reduce pathogen levels in order to prevent their environmental transmission. For the removal of suspended solids, pathogenic microorganisms and organic materials, several physical, biological, and chemical wastewater treatment processes are used. The nature of pathogenic microorganisms determine their removal/reduction efficiency by the wastewater treatment process [11]. Rotavirus and Cryptosporidium, as other enteric pathogens, are resistant against the processes used in wastewater treatment plants, and thus lead to their spread into the environment [12], particularly in surface waters. However, RV-A have been implicated in waterborne gastroenteritis outbreaks only sporadically [13]. Individuals with either symptomatic disease or asymptomatic infection excreted rotaviruses in sewage [14]. Monitoring of pathogens in urban sewage is therefore useful to evaluate the potential threatening viruses/protozoa widespread in the population, independent of disease severity and subject age. Monitoring of RV-A in sewage of WWTPs may provide an additional means to assess genotypes that also circulate in a given population [15]. However, detection and genotyping of RV-A in sewage may be affected by the simultaneous presence of several common or uncommon strains, and the segmented nature of the rotavirus genome may preclude the definite identification of the full genome constellation of detected RV-A. So, the objectives of the present study were to assess the occurrence and removal efficiency of Cryptosporidium species and rotavirus in the tested WWTP and identify the species of Cryptosporidium and RV-A genotypes.

\section{Materials and Methods}

\section{Samples and Sampling Site}

This study was carried out on a wastewater treatment plant (WWTP) located in Sharkeya governorate, Egypt, and operated by trickling filter technology. The designed capacity of the wastewater treatment plant is $12500 \mathrm{~m}^{3} /$ day. For preliminary treatment in the examined wastewater treatment plant a bar screen is installed to remove large objects such as sticks, cans and debris that may cause flow obstructions during the collection of domestic wastewater. FOG removal chambers contain grease, sand, oil traps and interceptors that are used to prevent these wastes from entering the plant and causing problems downstream. A primary sedimentation tank generally removes 30 to $40 \%$ of total BOD and 50 to $70 \%$ of suspended solids from raw sewage through anaerobic treatment. Trickling filters are used, in which an attached-growth biological process occurs through an inert medium to attract microorganisms that form a film on the medium surface. A rotatory or stationary distribution mechanism distributes wastewater from the top of the filter percolating it through the interstices of the film-covered medium. As the wastewater moves through the filter, the organic matter is adsorbed onto the film and degraded by a mixed population of aerobic microorganisms. The oxygen required for organic degradation is supplied by air circulating through the filter induced by natural draft or ventilation. A secondary sedimentation basin is a chamber in which microorganisms and other solids 
are settled, part of activated sludge is pumped back into an aeration basin and excess activated sludge is pumped to thickeners and then to a drying basin. The treated effluent is injected with a final concentration of $0.5-1 \mathrm{ppm}$ chlorine to destroy pathogenic microbes. A total of 72 water samples were collected from inlets $(n=36)$ and outlets $(n=36)$ of a wastewater treatment plant during a one-year period from July 2016 to June 2017. Three- and two-liter samples were collected in sterile bottles for viral and parasitological analysis, respectively. The removal rates (R) of the WWTP were calculated as the following equation;

$$
\mathbf{R}=\frac{\text { Total removed in ef fluents }}{\text { Positve samples in influents }} \times 100
$$

\section{Samples Concentration and Processing}

For virological examination, wastewater samples were separately concentrated by filtration through negatively charged nitrocellulose membranes $\left(0.45 \mu \mathrm{m}\right.$ pore size) after the addition of $\mathrm{AlCl}_{3}$ to a final concentration of $0.5 \mathrm{mM}$ and acidification to $\mathrm{pH}$ 3.5, and after passing through Whatmann No. 1 filter paper. The adsorbed viruses to the membrane were eluted with $75 \mathrm{ml}$ of $0.05 \mathrm{M}$ glycine buffer having pH 9.5 (using $\mathrm{HCl} 5 \mathrm{~N}$ ) and containing $3 \%$ beef extract (Lab-Limco powder, OXOID, UK) [17]. All samples were reconcentrated using an organic flocculation method according to Katzenelson et al. [18]. The eluate was acidified to $\mathrm{pH} 3.5$ using $\mathrm{HCl}(5 \mathrm{~N})$, centrifuged at $3000 \mathrm{rpm}$ for $15 \mathrm{~min}$, the supernatant was discarded and the pellet was dissolved in $1 \mathrm{ml}$ of $\mathrm{Na}_{2} \mathrm{HPO}_{4}(0.14 \mathrm{~N}$, $\mathrm{pH}$ 9). Samples were neutralized and kept at $-70^{\circ} \mathrm{C}$ until used [19].

For protozoological examination, wastewater samples (2L volume each) were concentrated by centrifugation at $4000 \mathrm{xg}$ at $4^{\circ} \mathrm{C}$ for $30 \mathrm{~min}$ (Sigma 3-18KS Centrifuge, Germany). The obtained pellets were separately resuspended in PBS $(\mathrm{pH}$ 7.4) and subsequently centrifuged for $15 \mathrm{~min}$ at $4300 \mathrm{xg}$ at $4^{\circ} \mathrm{C}$. The final pellet was purified using zinc sulfate solution (specific gravity, 1.3) according to Moodley et al. [20]. After purification, the obtained sediment was suspended in $280 \mu \mathrm{l}$ buffer AL (Qiagen, Hilden, Germany) for DNA extraction.

\section{Nucleic Acid Extraction}

Viral nucleic acids were extracted from $200 \mu \mathrm{l}$ of the concentrated sample using GeneJET Viral DNA and RNA Purification kit (THERMO SCIENTIFICUSA) according to the manufacturer's instructions. The obtained RNA was dissolved in $40 \mu 1$ of eluent and kept at $-70^{\circ} \mathrm{C}$ until used.

DNA of Cryptosporidium oocysts was extracted from in the purified samples using QIAamp DNA Stool Mini Kit (Qiagen, Hilden, Germany). Three freeze-thaw cycles, each cycle consisting of $2 \mathrm{~min}$ in liquid nitrogen followed by $2 \mathrm{~min}$ in boiling water, were performed before the application of the manufacturer's protocol. The obtained DNA was stored at $-20^{\circ} \mathrm{C}$ until used.

\section{Detecting Cryptosporidium spp. by PCR}

Cryptosporidium primers were described by Spano et al. (1997) [21], forward primer Cry9 (5'-GGACTGAAATACAGGCATTATCTTG-3') and reverse primer Cry-15 (5'-GTAGATAATGGAAGAGATTGTG-3') to amplify Cryptosporidium spp. cowp gene. Species identification was performed on PCR-positive samples for Cryptosporidium by using species-specific primers for Cryptosporidium parvum (SB012/SB012) and Cryptosporidium hominis [22, 23]. Amplification of DNA was performed using GoTaq G2 Green Master Mix (Promega, USA) according to the manufacturer manual. PCR reaction mixture per sample consisted of $12.5 \mu 1$ master mix, $3 \mu$ lemplate DNA, $1 \mu \mathrm{l}$ of forward and reverse primers (conc. $10 \mathrm{pmol}$ ), and $8.5 \mu \mathrm{l}$ nuclease-free water. PCR products were visualized using $2 \%$ agarose gel stained with ethidium bromide.

\section{Detecting Rotavirus Group A Using VP6}

According to Gray and Iturriza-Gomara [24], Nested RT-PCR was used for the detection of VP6 segment of rotavirus using the forward primer VP6-F primer 5'-GACGGVGCRACTACATGGT-3' and reverse primer VP6-R 5'-GTCCAATTCATNCCTGGTG-3' to amplify $382 \mathrm{bp}$ in first RT-PCR. Then the forward primer, VP6NF 5'-GCTAGAAATTTTGATACA-3', and the reverse primer, VP6-NR 5'-TCTGCAGTTTGTGAATC-3', were used to amplify $155 \mathrm{bp}$ in the second PCR. PCR products were analyzed on $2 \%$ agarose gel.

\section{Rotavirus Genotyping}

The multiplex semi-nested RT-PCR method was performed for genotyping of RV-A in water samples based on the characterization of VP7 and VP4 genes into G-type and P-type, respectively [24-26]. The cocktail of the primers in this method allowed us to determine G1-G6, G8-G11, P[1], and P[4]-P[11] types (Table 1). All PCR products were examined using 2\% gel electrophoresis. P and G genotypes were determined according to amplicon size.

\section{Results and Discussion}

Wastewater treatment steps consist of physical treatment (through sedimentation and filtration), biological treatment (trickling filters, stabilization ponds and activated sludge) and inactivation by chlorine, ozone and chlorine dioxide. The effluents of wastewater treatment plants may be contaminated by various groups of pathogenic microorganisms such as viruses, protozoan parasites, bacteria, and parasitic worms. 
Table 1. Primer sequences for genotyping of VP7 and VP4 genes of rotavirus.

\begin{tabular}{|c|c|c|c|c|c|c|}
\hline Primer name & Sequence $5^{`}-3^{`}$ & Sense & Target gene & Ref. & Primer set & Amplicon Length \\
\hline VP7-F & ATGTATGGTATTGAATATACCAC & + & 9 (VP7) & \multirow{9}{*}[24]{} & & \\
\hline VP7-R & AACTTGCCACCATTTTTTCC & - & 9 (VP7) & & VP7-F/VP7-R & 881 \\
\hline aBT1 & CAAGTACTCAAATCAATGATGG & + & 9 (VP7) & & aBT1/VP7-R & 618 \\
\hline $\mathrm{aCT} 2$ & CAATGATATTAACACATTTTCTGTG & + & 9 (VP7) & & $\mathrm{aCT} 2 / \mathrm{VP} 7-\mathrm{R}$ & 521 \\
\hline G3 & ACGAACTCAACACGAGAGG & + & 9 (VP7) & & G3/VP7-R & 682 \\
\hline aDT4 & CGTTTCTGGTGAGGAGTTG & + & 9 (VP7) & & $\mathrm{aDT} 4 / \mathrm{VP} 7-\mathrm{R}$ & 452 \\
\hline G8 & TTRTCGCACCATTTGTGAAAT & + & 9 (VP7) & & G8V/P7-R & 756 \\
\hline G9 & CTTGATGTGACTAYAAATAC & + & 9 (VP7) & & G9/ VP7-R & 179 \\
\hline G10 & ATGTCAGACTACARATACTGG & + & 9 (VP7) & & G10/VP7-R & 266 \\
\hline FT5 & CATGTACTCGTTGTTACGTC & - & 9 (VP7) & \multirow{3}{*}[25]{} & VP7-F/ FT5 & 729 \\
\hline DT6 & CTAGTTCCTGTGTAGAATC & - & 9 (VP7) & & VP7-F/ DT6 & 449 \\
\hline BT11 & GTCATCAGCAATCTGAGTTGC & - & 9 (VP7) & & VP7-F/ BT11 & 286 \\
\hline VP4-F & TATGCTCCAGTNAATTGG & + & 4 (VP4) & \multirow{8}{*}[24]{} & & \\
\hline VP4-R & ATTGCATTTCTTTCCATAATG & - & 4 (VP4) & & VP4-F/ VP4-R & 663 \\
\hline $2 \mathrm{~T}-1$ & CTATTGTTAGAGGTTAGAGTC & - & 4 (VP4) & & VP4-F/2T-1 & 483 \\
\hline $3 \mathrm{~T}-1$ & TGTTGATTAGTTGGATTCAA & - & 4 (VP4) & & VP4-F/3T-1 & 267 \\
\hline $1 \mathrm{~T}-1 \mathrm{D}$ & TCTACTGGRTTRACNTGC & - & 4 (VP4) & & VP4-F/1T-1D & 345 \\
\hline $4 \mathrm{~T}-1$ & TGAGACATG CAATTGGAC & - & 4 (VP4) & & VP4-F/4T-1 & 391 \\
\hline $5 \mathrm{~T}-1$ & ATCATAGTTAGTAGTCGG & - & 4 (VP4) & & VP4-F/5T-1 & 583 \\
\hline $\mathrm{P}(11)$ & GTAAACATCCAGAATGTG & - & 4 (VP4) & & VP4-F/ P(11) & 312 \\
\hline $\mathrm{pNCDV}$ & CGAACGCGGGGGTGGTAGTTG & + & 4 (VP4) & \multirow{3}{*}[26]{} & $\mathrm{pNCDV} / \mathrm{VP} 4-\mathrm{R}$ & 526 \\
\hline pUK & GCCAGGTGTCGCATCAGAG & + & 4 (VP4) & & $\mathrm{pUK} / \mathrm{VP} 4-\mathrm{R}$ & 459 \\
\hline pOSU & CTTTATCGGTGGAGAATACGTCAC & + & 4 (VP4) & & pOSU /VP4-R & 406 \\
\hline
\end{tabular}

Therefore, it is necessary to prevent environmental emissions of these pathogens through the application of the inactivation process on effluents before discharging it in surface water or use for irrigation [11]. Overall, the prevalence rates of rotavirus in influent $(n=36)$ and effluent $(n=36)$ samples of the examined WWTP were $47.2 \%$ and $33.3 \%$, respectively. These data were comparable with the results of previous studies showing the presence of RV-A not only in raw, but also in treated wastewater [27, 28]. In the present study the rotavirus genome was detected in $29(40.3 \%)$ out of 72 wastewater samples (raw and treated). An active laboratory monitoring and evaluation of the RV-A circulating genotypes will be required for surveilling the RV-A genetic diversity as well as their substantial characteristics, such as the seasonal fluctuations and the generation of new combinations or novel strains due to interspecies barrier broken [9]. Higher proportions were found in different countries like Tunis (72.4\%) [27], Venezuela (67\%) [29], Argentina (91.4 and 100\%) [28, 30], Brazil (85\%) [31], Italy (60.4\%) [32], USA (58.3\%) [33], and Uruguay (52.6\%) [34], but a lower prevalence of RV-A was observed in Egypt (8.3\%) [35], and China $(32.3 \%)$ [36]. The differences in environmental factors, virus levels in populations, methodology, primers used. might lead to different results. Also, the possibility of the presence of RNA inhibitors in environmental samples might also interfere with molecular detection [37]. There have only been limited data on the removal by trickling filter wastewater treatment process. In the current study, the removal efficiency of the virus was $29.4 \%$, which agreed with previous reports in other parts of the world, suggesting that even properly working wastewater treatment systems removed only $20-80 \%$ of enteric viruses [38,39] and confirming the high resistance of the virus to the sewage treatment process. Another environmental study showed that the removal of group A rotaviruses was $20 \%$ in two different wastewater treatment plants (trickling and activated sludge) [33].

Species-specific primers for Cryptosporidium hominis and Cryptosporidium parvum were applied on all positive samples for genus Cryptosporidium. The obtained results proved that all the samples were 
Table 2. Prevalence of rotavirus and Cryptosporidium parvum in influent and effluent of the examined WWTP.

\begin{tabular}{|c|c|c|c|c|c|c|c|}
\hline \multirow{2}{*}{ Sample types } & \multirow{2}{*}{$\begin{array}{l}\text { Collected } \\
\text { samples }\end{array}$} & \multicolumn{3}{|c|}{ Rotavirus } & \multicolumn{3}{|c|}{ Cryptosporidium parvum } \\
\hline & & No. & Prevalence (\%) & Removal (\%) & No. & Prevalence (\%) & Removal (\%) \\
\hline Influent & 36 & 17 & $47.2 \%$ & \multirow{3}{*}{29.4} & 15 & 41.7 & \multirow{3}{*}{40} \\
\hline Effluent & 36 & 12 & $33.3 \%$ & & 9 & 25 & \\
\hline Total & 72 & 29 & 40.3 & & 24 & 33.3 & \\
\hline
\end{tabular}

related to Cryptosporidium parvum. The prevalence of Cryptosporidium parvum in influents and effluents was $41.7 \%$ and $25 \%$, respectively. Other studies showed that the prevalence of Cryptosporidium oocysts ranged from 6.4 to $100 \%$ in raw wastewater from Brazil, China, Germany, Spain and USA [40-44]. The prevalence rates of Cryptosporidium oocysts varied in various studies even in the same country [37]. These differences in the prevalence rates might be due to the differences in the detection methods, sample volumes, number of the collected samples and the loads of the infection with Cryptosporidium in a given community.

Total removal rates in the examined WWTP were $29.4 \%$ and $40 \%$ for rotavirus and Cryptosporidium parvum, respectively (Table 2). Globally, rare studies were performed about the evolution of Cryptosporidium removal through trickling filters of wastewater treatment plants. Stadterman et al. [45] found that the activated sludge was better than trickling filters for the removal of seeded Cryptosporidium oocysts. Also, the reduction of Cryptosporidium from effluents was inefficient by using chlorine disinfection and by trickling filter [11]. Moreover, UV irradiation and ultrafiltration as tertiary treatment processes were able to reduce Cryptosporidium oocysts in secondary effluents [46, 47]. The importance of efficient wastewater treatment is to protect water bodies that receive the treated wastewater effluents from pathogen transmission [11].

The highest percentage of positive rotavirus in raw wastewater samples was detected in winter $(77.8 \%)$, with a maximum existence in December $(100 \%)$, then in autumn (66.7\%). These data were in agreement with the results of a previous study in Tunis showing that the highest prevalence of RV-A was in winter [27]. The highest percentage of positive samples for C. parvum (66.7\%) was observed in summer in influent samples, followed by $55.6,33.3$ and $11.1 \%$ in spring, autumn and winter, respectively. Other reports from

Table 3. Seasonal variations and genotyping of rotavirus group A in inlet and outlet of the examined wastewater treatment plant.

\begin{tabular}{|c|c|c|c|c|c|c|c|}
\hline Season & Month & $\begin{array}{c}\text { Occurrence of } \\
\text { Rotavirus in inlet }\end{array}$ & $\begin{array}{l}+ \text { ve } \\
\text { G-Type in } \\
\text { inlet }\end{array}$ & $\begin{array}{l}\text { +ve } \\
\text { P-Type } \\
\text { in inlet }\end{array}$ & $\begin{array}{c}\text { Occurrence of } \\
\text { Rotavirus in outlet }\end{array}$ & $\begin{array}{c}\text { +ve } \\
\text { G-Type } \\
\text { in outlet }\end{array}$ & $\begin{array}{l}\text { +ve P-Type } \\
\text { in outlet }\end{array}$ \\
\hline \multirow{4}{*}{ Summer } & June & $33.3 \%(1 / 3)$ & 1 & 1 & $0 \%(0 / 3)$ & ND & ND \\
\hline & July & $0 \%(0 / 3)$ & ND & ND & $0 \%(0 / 3)$ & ND & ND \\
\hline & Aug. & $33.3 \%(1 / 3)$ & 1 & 1 & $0 \%(0 / 3)$ & ND & ND \\
\hline & Total & $22.2 \%(2 / 9)$ & & & $0 \%(0 / 9)$ & & \\
\hline \multirow{4}{*}{ Autumn } & Sep. & $66.7 \%(2 / 3)$ & 1 & 1 & $66.7 \%(2 / 3)$ & 1 & 1 \\
\hline & Oct. & $66.7 \%(2 / 3)$ & ND & ND & $66.7 \%(2 / 3)$ & ND & ND \\
\hline & Nov. & $66.7 \%(2 / 3)$ & 2 & 1 & $66.7 \%(2 / 3)$ & 2 & 1 \\
\hline & Total & $66.7 \%(6 / 9)$ & & & $66.7 \%(6 / 9)$ & & \\
\hline \multirow{4}{*}{ Winter } & Dec. & $100 \%(3 / 3)$ & ND & ND & $66.7 \%(2 / 3)$ & ND & ND \\
\hline & Jan. & $66.7 \%(2 / 3)$ & 1 & 1 & $33.3 \%(1 / 3)$ & ND & ND \\
\hline & Feb. & $66.7 \%(2 / 3)$ & 2 & 2 & $66.7 \%(2 / 3)$ & 2 & 2 \\
\hline & Total & $77.8 \%(7 / 9)$ & & & $55.6 \%(5 / 9)$ & & \\
\hline \multirow{4}{*}{ Spring } & March & $33.3 \%(1 / 3)$ & 1 & ND & $33.3 \%(1 / 3)$ & 1 & ND \\
\hline & April & $33.3 \%(1 / 3)$ & 1 & 1 & $0 \%(0 / 3)$ & ND & ND \\
\hline & May & $0 \%(0 / 3)$ & ND & ND & $0 \%(0 / 3)$ & ND & ND \\
\hline & Total & $22.2 \%(2 / 9)$ & & & $11.1 \%(1 / 9)$ & & \\
\hline Total & \multicolumn{2}{|c|}{$47.2 \%(17 / 36)$} & $\begin{array}{c}58.8 \% \\
(10 / 17)\end{array}$ & $\begin{array}{l}47.1 \% \\
(8 / 17)\end{array}$ & $\begin{array}{l}33.3 \% \\
(12 / 36)\end{array}$ & $\begin{array}{l}50 \% \\
(6 / 12)\end{array}$ & $\begin{array}{l}33.3 \% \\
(4 / 12)\end{array}$ \\
\hline
\end{tabular}

ND: Not detectable 


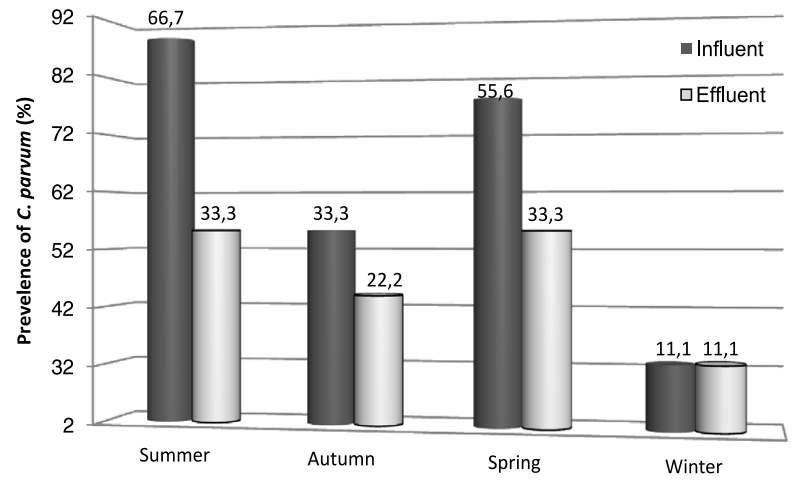

Fig. 1. Seasonal variations of C. parvum in influent and effluent of the examined WWTP.

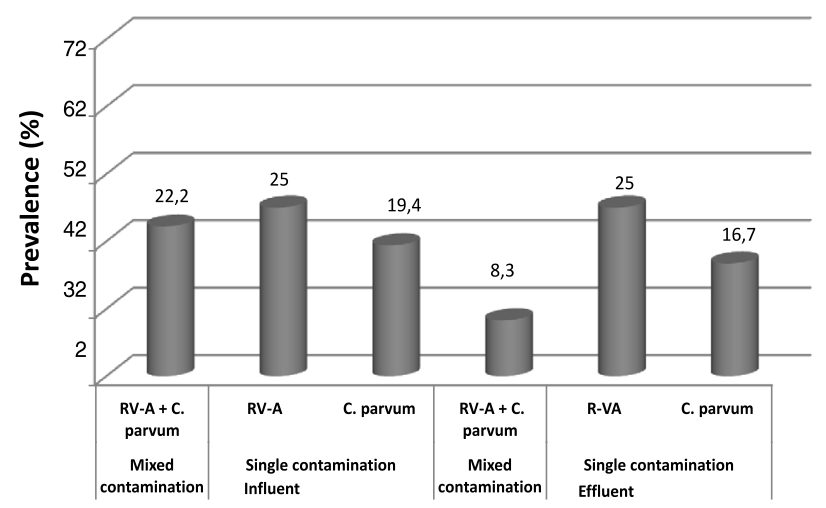

Fig. 2. Single and mixed contamination with rotavirus and $C$. parvum.

different countries showed that the seasonal distribution of Cryptosporidium oocysts were predominant during autumn and winter in Germany [48], spring and summer in Spain [49], and summer, autumn, and winter in Ireland [50].
The single contamination with rotavirus in raw sewage samples was $25 \%$, while that of $C$. parvum was $19.4 \%$. The rates of single contamination with rotavirus and C. parvum in effluent samples were 25 and $16.7 \%$, respectively. The mixed contamination with both rotavirus and $C$. parvum in influent and effluent samples reached 22.2 and $8.3 \%$, respectively (Table 3, Figs 1-2). Unfortunately, no data about mixed contamination with rotavirus and C. parvum in wastewater were available.

\section{Rotaviruses G and P Types}

Ten of the total 17 detected rotavirus strains in raw sewage could be $\mathrm{G}$ typed, while $41 \%$ of the samples were untypeable. G typing of RV-A strains showed 2 different types: G1 in 8 samples (47\% prevalence), and $\mathrm{G} 3$ in 2 samples $(12 \%)$. At the same time, 6 out of 12 rotavirus strains detected in treated wastewater could be $\mathrm{G}$ typed, while $50 \%$ of the positive-samples for rotavirus were untypeable. The most frequent $G$ type in treated sewage samples positive for rotavirus was G1 $(41.7 \%)(5 / 12)$, followed by G3 (8.3\%) (1/12). Also, No mixed contamination with $G$ types was noticed in any sewage samples (Table 3, Fig. 3). In the raw sewage samples, 8 of $17(47 \%)$ rotavirus-containing samples could be P typed, while 53\% of the samples were untypeable. The most frequent rotavirus $\mathrm{P}$ type was $\mathrm{P}[8](35.2 \%)(6 / 17)$, followed by $\mathrm{P}[6](5.9 \%)(1 / 17)$ and $\mathrm{P}[4](5.9 \%)(1 / 17)$. In the treated wastewater samples, 4 of $12(33.3 \%)$ rotavirus-positive samples could be $\mathrm{P}$ typed, and thus $66.7 \%$ of the samples were untypeable. The frequencies of $\mathrm{P}$ types were $\mathrm{P}[8]$ (25\%) (3/12) and $\mathrm{P}[4]$ 8.3\% (1/12). Rotavirus types $\mathrm{P}[1], \mathrm{P}[5], \mathrm{P}[7], \mathrm{P}[9], \mathrm{P}[10]$ and $\mathrm{P}[11]$ were not detected throughout the current study (Table 3, Fig. 3). In the current study, the prevalence of G1 and P[8] genotypes in sewage samples was in agreement with the predominance of G1 and $\mathrm{P}[8]$ genotypes in sewage

\section{RAW WASTEWATER}

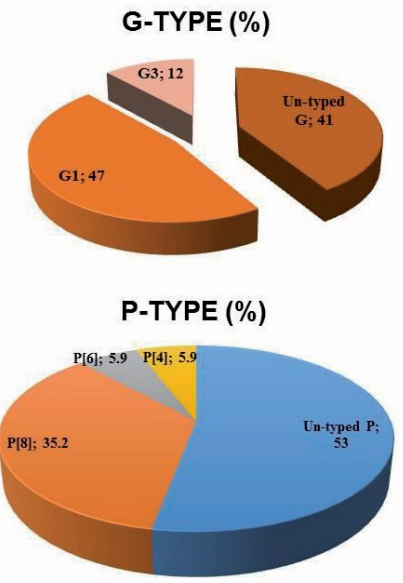

\section{TREATED WASTEWATER}

G-TYPE (\%)

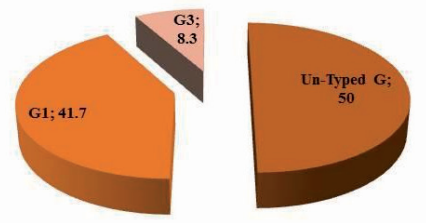

P-TYPE (\%)

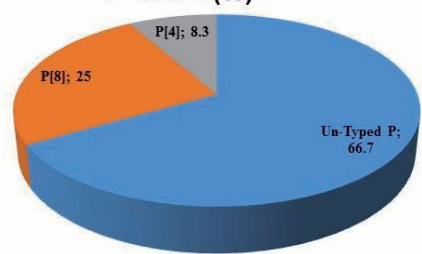

Fig. 3. Distribution of rotavirus genotypes in raw and treated wastewater samples. 
samples in other study [27]. Another environmental study reported the same genotypes in children suffering from diarrhea and in sewage at the same time [51]. In different countries, researchers found that G1 and $\mathrm{P}[8]$ genotypes were dominant in wastewater samples $[27,35,36]$. In the present study, other genotypes (P[4] and G3) were also detected. Genotypes G2 and $\mathrm{P}[4]$ were detected in Tunis, but with relatively high frequency in sewage samples [27]. The study conducted in Argentina showed approximate frequencies of the different genotypes (G2, G3, G4, G8, G9) in sewage and stool samples [30]. In another study conducted in Italy, other G types G2, G9, G4, G6, G3, and G26; and $\mathrm{P}$ types $\mathrm{P}[4], \mathrm{P}[6], \mathrm{P}[9], \mathrm{P}[14]$, and $\mathrm{P}[19]$ were found [32].

\section{Conclusions}

Several pathogenic strains of RV-A and Cryptosporidium parvum were not efficiently eliminated by trickling filter wastewater treatment processes, leading to the potential release of these pathogens from domestic sewage into water sources. The most prevalent types of RV-A strains in raw and treated sewage samples were $\mathrm{G} 1$ and $\mathrm{P}[8]$ genotypes. The virulent Cryptosporidium parvum was detected in all Cryptosporidium-positive samples. Concerning seasonal variations, the highest distribution rates for rotaviruses were in winter, while for Cryptosporidium species were in summer. This study also demonstrated the usefulness of environmental surveillance as an additional tool to determine the circulation of Cryptosporidium species and RV-A in a certain community. Large-scale studies are required to investigate the circulation of enteric pathogens in the Egyptian community, and the removal of these pathogens by different treatment technologies.

\section{Acknowledgements}

The authors are grateful to Mr. Ahmad Saad, analyst at Holding Company for Water and Wastewater, for his help in collecting wastewater samples. This work was financially supported by the National Research Centre, in-house project number 11060102.

\section{Conflict of Interest}

The authors declare that there is no conflict of interest.

\section{References}

1. EFSTRATIOU A., ONGERTH J.E., KARANIS P. Waterborne transmission of protozoan parasites: Review of worldwide outbreaks - An update 2011-2016. Water Research. 2017.

2. STERLING C.R., ADAM R.D. The Pathogenic Enteric Protozoa:: Giardia, Entamoeba, Cryptosporidium and Cyclospora (World Class Parasites, 8). 2006.

3. DUBEY J.P., SPEER C.A., FAYER R. Cryptosporidiosis of Man and Animals. CRC Press. Retrieved from http:// www.crcpress.com 2018.

4. DEN BOSSCHE D., CNOPS L., VERSCHUEREN J., VAN ESBROECK M. Comparison of four rapid diagnostic tests, ELISA, microscopy and PCR for the detection of Giardia lamblia, Cryptosporidium spp. and Entamoeba histolytica in feces. Journal of microbiological methods, 110, 78, 2015.

5. TATE J.E., BURTON A.H., BOSCHI-PINTO C., STEELE, A.D., DUQUE J., PARASHAR U.D. 2008 estimate of worldwide rotavirus-associated mortality in children younger than 5 years before the introduction of universal rotavirus vaccination programmes: A systematic review and meta-analysis. The Lancet Infectious Diseases, 12 (2), 136, 2012.

6. KNIPE D.N., HOWLEY P.M. Fields' Virology - Sixth Edition. Lippincott Williams \& Wilkins. 2013.

7. MATTHIJNSSENS J., CIARLET M., MCDONALD S.M., ATTOUI H., BÁNYAI K., BRISTER J.R.,VAN RANST M. Uniformity of rotavirus strain nomenclature proposed by the Rotavirus Classification Working Group (RCWG). Archives of Virology, 156 (8), 1397, 2011.

8. GAUCHAN P., NAKAGOMI T., SHERCHAND J.B., YOKOO M., PANDEY B.D., CUNLIFFE N.A., NAKAGOMI O. Continued Circulation of G12P[6] Rotaviruses Over 28 Months in Nepal: Successive Replacement of Predominant Strains. Tropical Medicine and Health, 41 (1), 7, 2013.

9. DA SILVA M.F.M., FUMIAN T.M., DE ASSIS R.M.S., FIALH A.M., CARVALHO-COSTA F.A., DA SILVA RIBEIRO DE ANDRADE J., LEITE J.P.G. VP7 and VP8* genetic characterization of group A rotavirus genotype G12P [8]: Emergence and spreading in the Eastern Brazilian coast in 2014. Journal of medical virology, 89 (1), 64, 2017.

10. QUAYE O., ROY S., RUNGSRISURIYACHAI K., ESONA M.D., XU Z., TAM K.I., BOWEN M.D. Characterisation of a rare, reassortant human G10P [14] rotavirus strain detected in Honduras, 113 (1), 9, 2018.

11. NASSER A.M. Removal of Cryptosporidium by wastewater treatment processes: a review. Journal of water and health, wh2015131. 2015.

12. BARCELÓ D., PETROVIĆ M. Waste Water Treatment and Reuse in the Mediterranean Region. The Handbook of Environmental Chemistry. 2011.

13. RÄSÄNEN S., LAPPALAINEN S., HALKOSALO A., SALMINEN M., VESIKARI T. Rotavirus gastroenteritis in Finnish children in 2006-2008, at the introduction of rotavirus vaccination. Scandinavian Journal of Infectious Diseases, 43 (1), 58, 2010.

14. ANDERSON E.J., SHIPPEE D.B., TATE J.E., LARKIN B., BREGGER M.D., KATZ B.Z., NOSKIN G.A., SEDERDAHL B.K., SHANE A.L., PARASHAR U.D., YOGEV R. Clinical characteristics and genotypes of rotavirus in adults. The Journal of infection, 70 (6), 683, 2015.

15. MONINI M., BIASIN A., VALENTINI S., CATTOLI G., RUGGERI F.M. Recurrent rotavirus diarrhoea outbreaks in a stud farm, in Italy. Veterinary Microbiology, 149 (1-2), 248, 2011. 
16. BERGLUND B., DIENUS O., SOKOLOVA E., BERGLIND E., MATUSSEK A., PETTERSSON T., LINDGREN P.E. Occurrence and removal efficiency of parasitic protozoa in Swedish wastewater treatment plants. Science of the Total Environment. 2017.

17. ROSE J.B., SINGH S.N., GERBA C.P., KELLEY L.M. Comparison of microporous filters for concentration of viruses from wastewater. Applied and Environmental Microbiology, 47 (5), 989, 1984.

18. KATZENELSON E., FATTAL B., HOSTOVESKY T. Organic flocculation: an efficient second step concentration method for the detection of viruses in tap water. Applied and Environmental Microbiology, 32 (4), 638, 1976.

19. EL-SENOUSY W.M., BARAKAT A.B., GHANEM H.E., KAMEL M.A. Molecular epidemiology of human adenoviruses and rotaviruses as candidate viral indicators in the Egyptian sewage and water samples. World Applied Sciences Journal, 27 (10), 1235, 2013.

20. MOODLEY P., ARCHER C., HAWKSWORTH D. Standard Methods for the Recovery and Enumeration of Helminth Ova in Wastewater, Sludge, Compost and Urine-Diversion Waste in South Africa. 2008.

21. SPANO F., PUTIGNANI L., MCLAUCHLIN J., CASEMORE D.P., CRISANTI A. PCR-RFLP analysis of the Cryptosporidium oocyst wall protein (COWP) gene discriminates between $\mathrm{C}$. wrairi and $\mathrm{C}$. parvum, and between C. parvum isolates of human and animal origin. FEMS Microbiology Letters, 150 (2), 209, 1997.

22. WU Z., NAGANO I., MATSUO A., UGA S., KIMATA I., ISEKI M., TAKAHASHI Y. Specific PCR primers for Cryptosporidium parvum with extra high sensitivity. Molecular and Cellular Probes, 14 (1), 33, 2000.

23. SOLIMAN R.H., OTHMAN A.A. Evaluation of DNA melting curve analysis real-time PCR for detection and differentiation of Cryptosporidium species. Parasitologists United Journal, 2 (1), 47, 2009.

24. GRAY J., ITURRIZA-GÓMARA M. Rotaviruses. Methods in molecular biology (Clifton, N.J.), 665, 325, 2011.

25. GOUVEA V., SANTOS N., DO CARMO TIMENETSKY $M$. Identification of bovine and porcine rotavirus $G$ types by PCR. Journal of Clinical Microbiology. 1994.

26. GOUVEA V., SANTOS N., DO CARMO TIMENETSKY M. VP4 typing of bovine and porcine group A rotaviruses by PCR. Journal of Clinical Microbiology, 32 (5), 1333, 1994

27. HASSINE-ZAAFRANE M., KAPLON J., BEN SALEM I., SDIRI-LOULIZI K., SAKLY,N., POTHIER P., AMBERT-BALAY K. Detection and genotyping of group A rotaviruses isolated from sewage samples in Monastir, Tunisia between April 2007 and April 2010. Journal of Applied Microbiology, 119 (5), 1443, 2015.

28. BARRIL P.A., FUMIAN T.M., PREZ V.E., GIL P.I., MARTÍNEZ L.C., GIORDANO M.O., NATES S.V. Rotavirus seasonality in urban sewage from Argentina: Effect of meteorological variables on the viral load and the genetic diversity. Environmental Research, 138, 409, 2015.

29. RODRÍGUEZ-DÍAZ J., QUERALES L., CARABALLO L., VIZZI E., LIPRANDI F., TAKIFF H., BETANCOURT W.Q. Detection and characterization of waterborne gastroenteritis viruses in urban sewage and sewagepolluted river waters in Caracas, Venezuela. Applied and Environmental Microbiology, 75 (2), 387, 2009.

30. BARRIL P.A., GIORDANO M.O., ISA M.B., MASACHESSI G., FERREYRA L.J., CASTELLO A.A.,
NATES S.V. Correlation between rotavirus A genotypes detected in hospitalized children and sewage samples in 2006, Córdoba, Argentina. Journal of Medical Virology, 82 (7), 1277, 2010.

31. FUMIAN T.M., GAGLIARDI LEITE J.P., ROSE T.L., PRADO T., MIAGOSTOVICH M.P. One year environmental surveillance of rotavirus specie A (RVA) genotypes in circulation after the introduction of the Rotarix ${ }^{\circledR}$ vaccine in Rio de Janeiro, Brazil. Water Research, 45 (17), 5755, 2011

32. RUGGERI F.M., BONOMO P., IANIRO G., BATTISTONE A., DELOGU R., GERMINARIO C., FIORE L. Rotavirus genotypes in sewage treatment plants and in children hospitalized with acute diarrhea in Italy in 2010 and 2011. Applied and Environmental Microbiology, 81 (1), 241, 2015

33. KITAJIMA M., IKER B.C., PEPPER I.L., GERBA C.P. Relative abundance and treatment reduction of viruses during wastewater treatment processes - Identification of potential viral indicators. Science of the Total Environment, 488-489 (1), 290, 2014.

34. TORT L.F.L., VICTORIA M., LIZASOAIN A., GARCÍA M., BEROIS M., CRISTINA J., ... COLINA R. Detection of Common, Emerging and Uncommon VP4, and VP7 Human Group A Rotavirus Genotypes from Urban Sewage Samples in Uruguay. Food and Environmental Virology, 7 (4), 342, 2015.

35. KAMEL A.H., ALI M.A., EL-NADY,H.G., AHO S., POTHIER P., BELLIOT G. Evidence of the co-circulation of enteric viruses in sewage and in the population of Greater Cairo. Journal of applied microbiology, 108 (5), 1620, 2010.

36. HE X.Q., CHENG L., ZHANG D.Y., XIE X.M., WANG D.H., WANG Z. One-year monthly survey of rotavirus, astrovirus and norovirus in three sewage treatment plants (STPs) in Beijing, China and associated health risk assessment. Water Science and Technology, 64 (6), 1202, 2011.

37. HASSINE-ZAAFRANE M., SDIRI-LOULIZI K., SALEM I.B., KAPLON J., AYOUNI S., AMBERTBALAY K., AOUNI M. The molecular epidemiology of circulating rotaviruses: Three-year surveillance in the region of Monastir, Tunisia. BMC Infectious Diseases, 11, 2011.

38. HE X.Q., CHENG L., ZHANG D.Y., LI W., XIE X.M., MA M., WANG Z.J. First molecular detection of group a rotaviruses in drinking water sources in Beijing, China. Bulletin of Environmental Contamination and Toxicology, 83 (1), 120, 2009

39. LI D., GU A.Z., ZENG S.-Y., YANG W., HE M., SHI H.C. Monitoring and evaluation of infectious rotaviruses in various wastewater effluents and receiving waters revealed correlation and seasonal pattern of occurrences. Journal of applied microbiology, 110 (5), 1129, 2011.

40. NETO R.C., SANTOS J.U., FRANCO R.M.B. Evaluation of activated sludge treatment and the efficiency of the disinfection of Giardia species cysts and Cryptosporidium oocysts by UV at a sludge treatment plant in Campinas, south-east Brazil. Water Science and Technology, 54 (3), 89, 2006.

41. FU C.Y., XIE X., HUANG J.J., ZHANG T., WU Q.Y., CHEN J.N., HU H.Y. Monitoring and evaluation of removal of pathogens at municipal wastewater treatment plants. Water Science and Technology, 61 (6), 1589, 2010.

42. GALLAS-LINDEMANN C., SOTIRIADOU I., PLUTZER J., KARANIS P. Prevalence and distribution 
of Cryptosporidium and Giardia in wastewater and the surface, drinking and ground waters in the Lower Rhine, Germany. Epidemiology \& Infection, 141 (1), 9, 2013.

43. CHIRISA I., BANDAUKO E., MATAMANDA A., MANDISVIKA G. Decentralized domestic wastewater systems in developing countries: the case study of Harare (Zimbabwe). Applied Water Science. 2016.

44. RAMO A., DEL CACHO E., SÁNCHEZ-ACEDO C., QUÍLEZ J. Occurrence and genetic diversity of Cryptosporidium and Giardia in urban wastewater treatment plants in north-eastern Spain. Science of the Total Environment. 2017.

45. STADTERMAN K.L., SNINSKY A.M., SYKORA J.L., JAKUBOWSKII W. Removal and inactivation of Cryptosporidium oocysts by activated sludge treatment and anaerobic digestion. Water Science and Technology, 31 (5-6), 97, 1995.

46. LONIGRO A., POLLICE A., SPINELLI R., BERRILLI F., DI CAVE D., D'ORAZI C., BRANDONISIO O. Giardia cysts and Cryptosporidium oocysts in membrane-filtered municipal wastewater used for irrigation. Applied and environmental microbiology, 72 (12), 7916, 2006.

47. SOLIMAN A., EL-ADAWY A., ABD EL-AAL A.A., ELMALLAWANY M.A., NAHNOUSH R.K., ABD
EIAGHNI A.R., MOHSEN A. Usefulness of Sunlight and Artificial UV Radiation Versus Chlorine for the Inactivation of Cryptosporidium Oocysts: An in Vivo Animal Study. Open Access Macedonian Journal of Medical Sciences, 6 (6), 975, 2018.

48. AJONINA C., BUZIE C., AJONINA I.U., BASNER A., REINHARDT H., GULYAS H., OTTERPOHL R. Occurrence of Cryptosporidium in a wastewater treatment plant in North Germany. Journal of Toxicology and Environmental Health, Part A, 75 (22-23), 1351, 2012.

49. CASTRO-HERMIDA J.A., GARC\$\$\$\$\$IA-PRESEDO I., ALMEIDA A., GONZÁLEZ-WARLETA M., DA COSTA J.M.C., MEZO M. Contribution of treated wastewater to the contamination of recreational river areas with Cryptosporidium spp. and Giardia duodenalis. Water Research, 42 (13), 3528, 2008.

50. CHENG H.-W., BROADERS M.A., LUCY F.E., MASTITSKY S.E., GRACZYK T.K. Determining potential indicators of Cryptosporidium oocysts throughout the wastewater treatment process. Water Science and Technology, 65 (5), 875, 2012.

51. DUNGENI M., MOMBA M.N.B. The abundance of Cryptosporidium and Giardia spp. in treated effluents produced by four wastewater treatment plants in the gauteng province of South africa. Water SA, 36 (4), 425, 2010. 